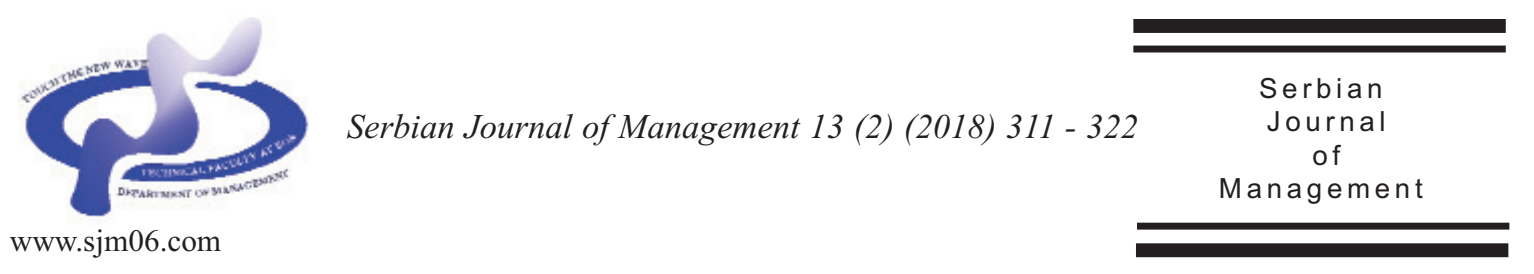

\title{
CONTROL ON TEAMS: A MODEL AND EMPIRICAL EVIDENCE FROM BULGARIA
}

\author{
Maya Rumenova Lambovska* \\ University of National and World Economy, Department of Management, \\ Students’ Town “Hristo Botev”, 1700 Sofia, Bulgaria
}

(Received 24 July 2017; accepted 13 March 2018)

\begin{abstract}
This paper suggests an original model for control on teams. The originality of the model is associated with a combination of management concepts and mathematical theories of fuzzy logic and fuzzy sets. In addition to the team control model, the author proposes a toolkit for measurement and evaluation of team performance. The toolkit incorporates fuzzy techniques and tools for quantification of evaluations, decision-making, study of joint influences and hidden effects. The results from testing the team control model at a Bulgarian University are also presented and discussed in this paper.
\end{abstract}

Key words: team, control, performance evaluation, Fuzzy techniques, Bulgarian university

\section{INTRODUCTION}

The importance of team approach to the contemporary organizations' management is considered nowadays to be unquestionable in management theory and practice. Firstly, scientific literature focuses on teams' contribution to the success of organizations due to the synergic effect realized by teams (Parker, 2011). Secondly, team approach forms the basis of a number of modern organizational structures such as adhocracy, organizational democracy, and others
(Mintzberg, 2013). Thirdly, the team approach is defined in theory and it has been applied in managerial practice in recent years as a key organizational strategy (Salas et al., 2004; Slavić et al., 2014).

Nevertheless, at that time the issue of control on teams is only partially developed in the scientific literature. This issue is associated in management theory mainly with problems of team effectiveness (Burns et al., 2012; Salas et al., 2004) and evaluation of team performance (Kozlowski \& Bell, 2013; McIntyre \& Tedrow, 2004). The

\footnotetext{
* Corresponding author: mlambovska@abv.bg
}

DOI: $10.5937 /$ sjm13-14633 
absence of an overall, scientifically substantiated concept of team control in general management theory shifts the focus and limits the problem to one or two areas of management science - performance management and management theory of measurement. Those partial views of team control, as well as ignorance of links with the other areas of management, prevent combining scientific achievements not only of management disciplines but also of other sciences.

On the other hand, development of mathematics in the era of knowledge gives an opportunity to develop a team control model at a contemporary scientific level. The team control model presented here could be considered to be a step forward in achieving that result. The model ability to operate is proven by testing it at Todor Kableshkov University of Transport in Sofia during the academic year 2015-2016.

\section{RESEARCH BASE}

This paper is aimed at suggesting an original model for control on teams. The originality of the model is associated with a combination of classical and contemporary achievements of management and mathematical theories of fuzzy logic and fuzzy sets.

The team control model, suggested here, is based on two main research restrictions:

1. Qualitative information is predominantly employed in the team control process.

2. The new better performance of each team is achieved as a result of the implementation of a set of managerial decisions concerning team features.

The significance of the author's model consists in overcoming theoretical deficits on the issues of team control. Furthermore, the model is based on a modern team control methodology performed through fuzzy logic and other fuzzy techniques that fills a gap in the team management toolkit. In this sense, besides its theoretical focus, this paper is also relevant to managerial practice.

The author of this paper has two research tasks:

- Clarifying methodological bases and content of the team control model suggested here;

- Proving the ability of the model to operate.

The author's research thesis is the following: It is possible to develop a model for the team control process combining achievements of management and fuzzy theories, and to increase the effectiveness of that process in organizations. This possibility could be considered as a consequence of the current level of applied mathematics, in particular, fuzzy theories, and the state of the scientific management literature in the field of team control. Furthermore, the necessity to develop such a model stems primarily from the importance of team approach to the modern organizations' management.

\section{METHODOLOGICAL BASES}

In methodological terms, the team control model is based on theories of organizational behaviour, human resource management, social and applied psychology, management control, performance management, fuzzy logic and fuzzy sets.

Theories of organizational behaviour, human resource management, social and applied psychology are used as a basis for clarifying the nature and features of teams as 
an object of control as well as for choosing input variables for the team control model.

From a management point of view, particularly important theories are those of management control and performance management. Management control theory is the theoretical ground on which the author's concept of team control is built. The present team control model is based on the theoretical control model developed by $\mathrm{O}$. Simeonov (2010). The differences with Simeonov's model refer to the essence of the team control model and the number of its elements. Two reasons underlie the necessity for a change in Simeonov's model. The first reason is the application of fuzzy sets and fuzzy logic tools. The second one is the dropout of the "action planning system" (Mintzberg, 2013) from a number of contemporary organizational structures based on team approach (Guinn, 1987).

The importance of performance management for the present concept refers to some basic approaches of that theory applied to procedures of the team control model. The most important approaches are management by objectives and multi-dimensional evaluation. Another application of that theory is to be a basis for selecting and defining output variables of the team control model. A number of terms used in the author's concept are defined in the context of performance management including team performance, team control, measurement and evaluation of team performance, team performance improvement, etc.

Theories of fuzzy logic and fuzzy sets form the instrumental basis of the team control model. The fuzzy logic theory provides a methodology for dealing with linguistic (qualitative) variables; facilitates common sense reasoning with imprecise and vague propositions; and serves as a basis for decision analysis and control actions (Bojadziev \& Bojadziev, 1997; Božanić et al., 2015). The fuzzy sets theory is considered to be an analogue of the probability theory applied to the processing of information based on subjective, qualitative evaluations under uncertainty (Kaufman \& Gil-Aluja, 1990; Živković et al, 2016). In this team control model, fuzzy logic is used to evaluate teams' performance and the necessity to react to teams. Fuzzy sets tools are used in the model for quantification of evaluations, forecasting, study of joint influences and hidden effects.

\section{TEAM CONTROL MODEL}

\subsection{Basic terms of the team control model}

- Team - A social entity where individuals are united on the basis of common objectives and values. The author's definition is close to Aubert's perception of a team (1991). Each team is described by its features. In this team control model, they are classified into three groups: features of team formation, features of team activities, and features of team results (see Figure 2). This classification is based on Margerison \& McCann's idea about determinants of the group/ team effectiveness (1990).

- Team management - Management of team performance.

- Control on teams:

o From the control theory point of view - A management process, based on the feedback principle, ensuring achievement of planned (target) level of teams' performance.

o From the performance management 
point of view - A process of measuring and evaluating the performance of teams aimed at improving their performance.

- Team performance - An integral indicator for the team state. It is defined in this paper as an aggregate evaluation of parties concerned with the state of the team, reflecting in total their views about team formation, team activities and team results.

- Team performance measurement Team performance quantification.

- Team performance evaluation Assignment of an evaluation as regards the value of the quantified team performance. The definitions of team performance measurement and evaluation in this paper are based on Ilgen \& Schneider's perceptions (1991).

- Team performance improvement Achieving an aggregate evaluation of a new state of the team which is higher than the previous actual evaluation of that team (Caldwell, 2000).

- Input variables of the team control model - They are identified with the three groups of team features: team formation, team activity and team results.

- Output variables of the team control model - They are identified with the team performance and the necessity to react to the team.

- Controllable indicators of the team control process - Team features are viewed as controllable indicators in this model. They are presented in detail in Figure 2.

- Team control system - It is described by its elements (Simeonov, 2010) incl. object, subject-matter, subject of control, team control toolkit, results and effectiveness of the team control system functioning.

- Effectiveness of the team control system - The extent to which the objective of improving teams' performance in the organization has been achieved (INTOSAI, 2004). It is evaluated in the model by "average deviation in teams' performance progress" indicator. According to control theory, an effective control system (team control system in this context) allows zero or, at worst, minimal deviation (Simeonov, 2010) from the target performance (teams' performance forecast in this context).

- Average deviation in teams' performance progress - A mean of differences between the actual and forecast progress in the performance of all teams controlled in the organization. The actual progress in team performance is defined as a difference between the second and the first actual evaluation of the team performance, and the forecast progress - as a difference between the forecast and the first actual evaluation of the team performance (INTOSAI, 2004).

\subsection{Characteristics of the team control model}

The author's model for the team control process is presented in Figure 1.

Specificity of the team control model in this paper consists primarily in the way in which team performance is understood and evaluated. Team performance is evaluated in the model by fuzzy logic tools. The evaluation process (see Figure 2) consists in the transformation of team evaluations (qualitative/ quantitative) by input variables through fuzzy logic rules into team evaluations by output variables (quantitative/ qualitative). Secondly, the specificity of the team control model refers to a proper combination of fuzzy tools and techniques for quantification of evaluations/ forecasts, decision-making, study of joint influences and hidden effects. 


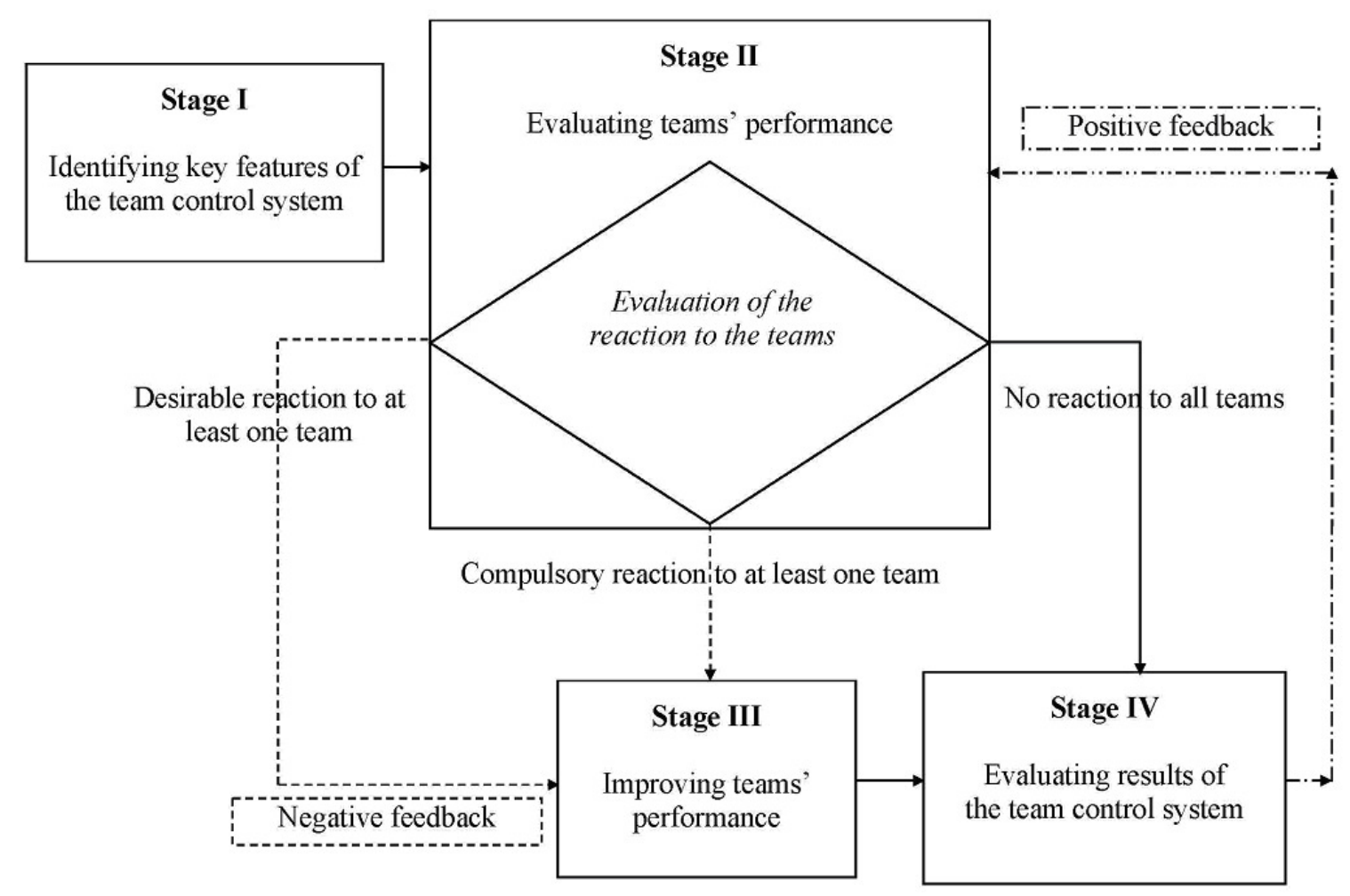

Figure 1. Author's model for control on teams

According to the author's model, the team control process covers four stages:

- $\quad$ Stage I - Identifying key features of the team control system;

- Stage II - Evaluating teams' performance;

- Stage III - Improving teams' performance;

- Stage IV - Evaluating results of the team control system.

The key features of the team control system are identified in the first stage of the team control process including object, subject-matter, and subject of control as well as initialization features of the applied tools. Teams are the object of control. Parties concerned with teams' performance are viewed as the subject of control. These are group entities of the team control process as follows: the team control committee of the organization, the controlled lecturing teams, and the other parties concerned. Team control subject-matter is associated with controllable indicators of the control process (Simeonov, 2010). The initialization features of the tools are states of the fuzzy logic tools by which team performance is evaluated in the model. These are features of linguistic variables (input and output) and fuzzy logic rules for teams' evaluating. Logical rules for evaluating teams in the model are defined for each output variable. Besides fuzzy logic, other tools used in the first stage are focus groups and logical operations with fuzzy numbers.

Teams' performance and the necessity to react to teams under first actual monitoring are evaluated in the second stage of the team control process. As a result, the so-called 
"first actual evaluations of teams" by both output variables (team performance and reaction to the team) are generated. The tools used in the second stage are focus groups, survey method, fuzzy logical rules, and mathematical operations with confidence intervals and fuzzy numbers (triangular and trapezoidal), fuzzy expertons, fuzzy random influence matrices. The second stage of the control process consists of the following procedures: development of scales for linguistic variables, evaluation of teams by

Input linguistic variables

\begin{tabular}{|l|}
\hline \multicolumn{1}{|c|}{ “Team formation" input variable } \\
Team size \\
Team staff (compositionle indicators: \\
Team roles and status \\
Team standards \\
Clearly defined team objectives and tasks \\
\hline \hline \multicolumn{1}{|c|}{ "Team activity" input variable } \\
Controllable indicators: \\
Team Process indicators: \\
- Systematic and flexible team processes \\
and procedures \\
- Team decision-making \\
- Team collaboration \\
Effectiveness of team communications \\
Team interpersonal dynamics: \\
- Team climate \\
Team cohesion \\
- Support (Empathy) \\
Trust \\
Leadership \\
Common (shared) values \\
Commitment of the team members
\end{tabular}

"Team results" input variable Controllable indicators:

Achievement of team objectives

Parties' concerned satisfaction with the team performance

Team members' satisfaction input linguistic variables under the first actual monitoring, generation of the first actual evaluations of teams by output linguistic variables through fuzzy sets and fuzzy logic toolkit, and decision-making for corrective actions to be taken toward teams. The evaluations of scales and teams by input variables are described quantitatively through fuzzy trapezoidal numbers and the evaluations of teams by output variables through fuzzy subsets.

\section{Output linguistic variables}

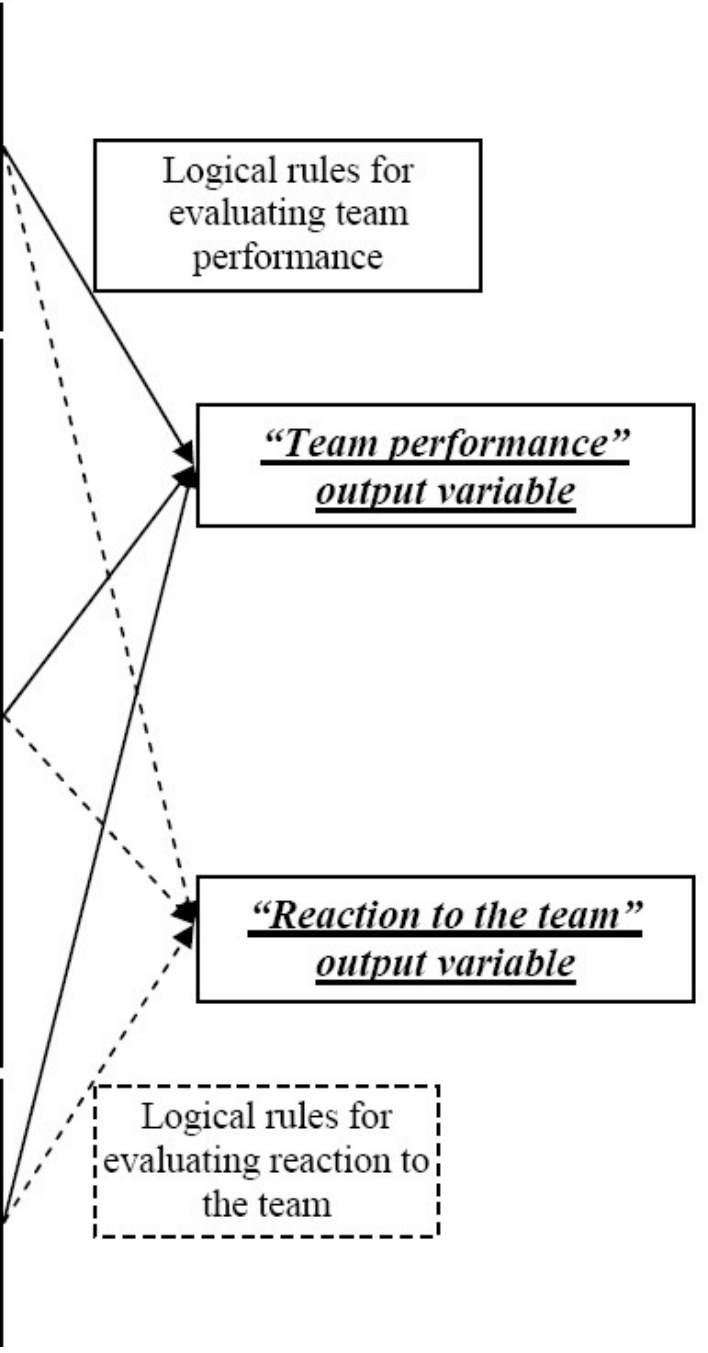

Figure 2. Team evaluation under the team control model 
The third stage of the team control process is aimed at improving the performance of teams in the organization. As a main restriction, a requirement is introduced that a new better performance of each team is achieved as a result of the implementation of a set of managerial decisions concerning team features. The purpose is to raise minimal evaluations of teams by controllable indicators of the input variables determined in the first actual monitoring. The products of the third stage are forecasts for teams' evaluations by both output variables. The tools used in the third stage are the same as those used in the second stage. In addition, a maxmim function with expertons formed by confidence intervals with four evaluations is applied. The following procedures are realized at this stage: generation of a set of managerial decisions to improve teams' performance, evaluating the forecast effect of managerial decisions on controllable indicators of the input variables, evaluating mutual and joint influences between managerial decisions and minimal evaluations of teams by controllable indicators of the input variables, generation of forecasts for teams' evaluations by output variables.

The results of the team control system in the organization are evaluated in the fourth stage of the process. The tools used in this stage are the same as those in the second stage. The procedures in the fourth stage are the following: evaluating the actual effect of the managerial decisions implementation by generating second actual teams' evaluations by output variables, diagnostics of hidden effects between managerial decisions and teams' evaluations by input variables, evaluating the effectiveness of the team control system in the organization, drawing conclusions

and formulating recommendations to the team control system and teams.

\section{TESTING THE TEAM CONTROL MODEL}

\subsection{Results from testing}

The author's team control model was tested with ten lecturing teams at Todor Kableshkov University of Transport (TKUT), Sofia in 2015-2016 academic year. All teams consisted of two lecturers- a professor and an assistant professor. Five lecturing teams taught economic subjects and the others - technical subjects. For the purpose of testing, questionnaires were developed based on scientific literature achievements and systems for quality evaluation at TKUT (Kolev et al., 2012).

As parties concerned with the lecturing teams' performance were viewed the team control committee at TKUT, the controlled lecturing teams and the students.

The following specific features of the lecturing teams by input variable "team results" were identified at TKUT: achieving the objectives of the lecturing teams, satisfaction of the team control committee and the students as parties concerned, satisfaction of the lecturing teams' members. Controllable indicators of the feature "achieving the objectives of the lecturing teams" were: high grades of students, study material taught, attendance of team members, continuous evaluation during the semester, students' term papers, published materials by the team, and syllabus updating. Students' satisfaction was evaluated by the following controllable indicators: up-to-date syllabus, practical focus of the subject, 
Table 1. Results of the team control system at Todor Kableshkov University of Transport for 2015-2016 academic year defuzzified by the centre of area method

\begin{tabular}{rcccccc}
\hline Team & $\begin{array}{c}\text { First actual } \\
\text { team } \\
\text { performance } \\
\text { evaluation }\end{array}$ & $\begin{array}{c}\text { Second actual } \\
\text { team } \\
\text { performance } \\
\text { evaluation }\end{array}$ & $\begin{array}{c}\text { Forecast of } \\
\text { team } \\
\text { performance } \\
\text { evaluation }\end{array}$ & $\begin{array}{c}\text { Actual team } \\
\text { performance } \\
\text { progress }\end{array}$ & $\begin{array}{c}\text { Forecast of } \\
\text { team } \\
\text { performance } \\
\text { progress }\end{array}$ & $\begin{array}{c}\text { Deviation in } \\
\text { team } \\
\text { performance } \\
\text { progress }\end{array}$ \\
\hline 1 & 1 & 2 & 3 & $4=2-1$ & $5=3-1$ & $6=4-5$ \\
\hline 2 & 0.7159 & 0.7687 & 0.7397 & 0.0531 & 0.0241 & 0.029 \\
3 & 0.6802 & 0.7397 & 0.7247 & 0.0595 & 0.0445 & 0.015 \\
4 & 0.6716 & 0.7388 & 0.7219 & 0.0672 & 0.0503 & 0.0169 \\
5 & 0.6799 & 0.7335 & 0.7236 & 0.0536 & 0.0437 & 0.0099 \\
6 & 0.6696 & 0.7328 & 0.7118 & 0.0632 & 0.0422 & 0.021 \\
7 & 0.6769 & 0.7275 & 0.7068 & 0.0506 & 0.0299 & 0.0207 \\
8 & 0.6546 & 0.7312 & 0.6766 & 0.0766 & 0.022 & 0.0546 \\
9 & 0.68 & 0.7304 & 0.6966 & 0.0504 & 0.0166 & 0.0338 \\
10 & 0.6419 & 0.7201 & 0.7107 & 0.0782 & 0.0688 & 0.0094 \\
\hline Average deviation & 0.6755 & 0.7203 & 0.7102 & 0.0448 & 0.0347 & 0.0101 \\
\hline
\end{tabular}

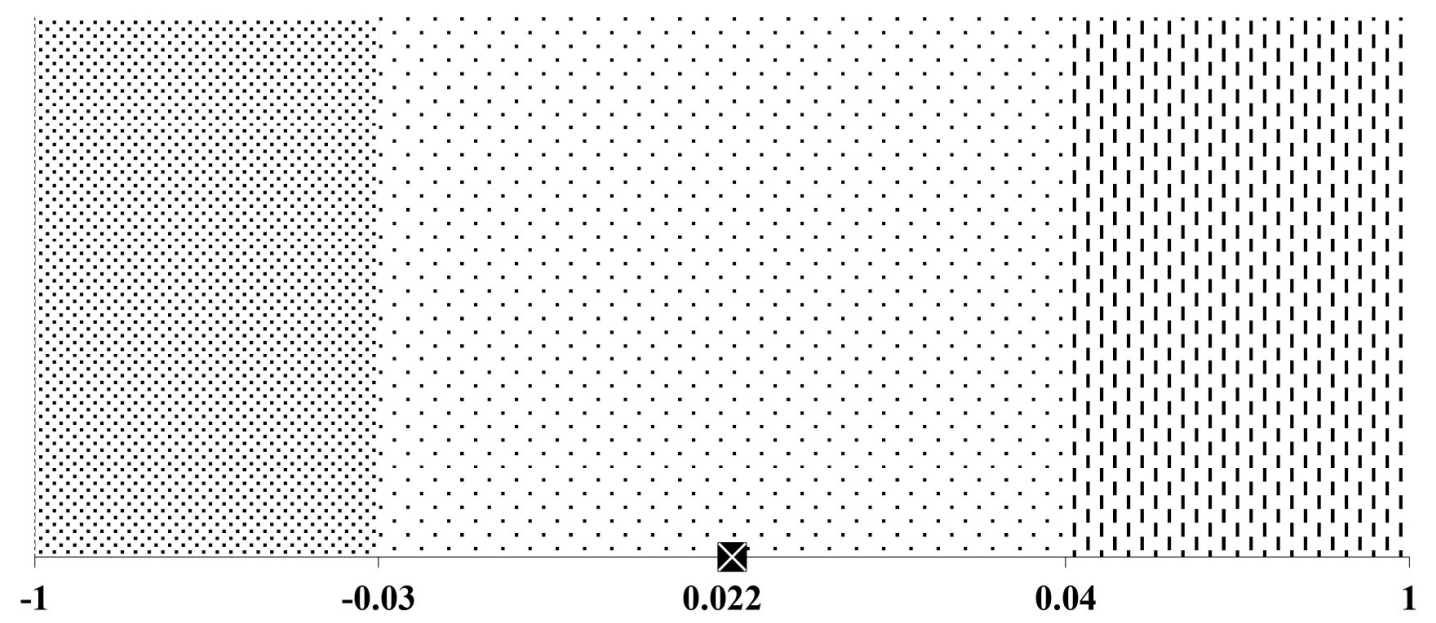

Effectiveness of the team control system at Todor Kableshkov University of Transport for 2015-2016 academic year

Ineffective team control system with a negative deviation at Todor Kableshkov University of Transport

$\because \cdots \cdots$ Ineffective team control system with a positive deviation at Todor Kableshkov University of Transport

.... Effective team control system at Todor Kableshkov University of Transport

-- $\mathbf{X - -}$ Effectiveness of the team control system at Todor Kableshkov University of Transport for 2015-2016 academic year

Figure 3. Effectiveness of the team control system at Todor Kableshkov University of Transport for 2015-2016 academic year 
objectivity in evaluation, level of teaching, resource provision of the team, characteristics of the lecturers forming the team, meeting the expectations about the subject.

A set of managerial decisions was implemented in 2015-2016 at TKUT for improving the lecturing teams' performance including subject syllabus update, introducing teamwork into seminars, solving practical cases/ tasks in seminars, change of criteria and procedure for students' evaluation, change the way of conducting the seminars, giving extra materials to train the students.

The main results from testing the team control system at TKUT in 2015-2016 academic year are presented in Table 1 and in Figure 3. All fuzzy quantitative evaluations are defuzzified; i.e. the fuzzy subsets and numbers are presented discretely (Bojadziev \& Bojadziev, 1997). Defuzzification was made by the centre of area method.

\subsection{Discussion}

The experimental team control system, applied at TKUT in 2015-2016 academic year has a few main features (see Table 1 and Figure 3), as follows:

- Firstly, there are three possible states on the scale by which the effectiveness of the team control system at TKUT was evaluated: "ineffective evaluation with a negative deviation", "effective evaluation" and "ineffective evaluation with a positive deviation" (see Figure 3). According to the scale, the ineffective team control system is characterized by a large negative (up to 0.03 ) and a large positive (above 0.04) average deviation in the teams' performance progress. These values of the average deviation in progress are associated respectively with a failure and an overachievement of the lecturing teams' objectives. The team control system at TKUT is evaluated to be effective for a very little failure $[-0.031 ; 0)$ and a very little overachievement $(0 ; 0.04]$ of teams' objectives.

- Secondly, the positive value of the average deviation in teams' performance progress at TKUT in 2015-2016 academic year $(0.022$ for all ten teams, see Table 1$)$ indicates that the teams' objectives were achieved. Therefore, the experimental team control system at TKUT functioned successfully.

- Thirdly, the experimental team control system at TKUT could be defined as effective. According to the effectiveness scale (see Figure 3), the average deviation in teams' performance progress at TKUT $(0.022$, see Table 1$)$ fell within the range [$0.03 ; 0.04]$ of the evaluation "effective control system".

- Fourthly, the effectiveness evaluation of the experimental team control system at TKUT in the academic year 2015-2016 was close to but did not coincide ideally with zero average deviation in the performance progress of the lecturing teams. In this sense, there were opportunities for a further increase in the effectiveness of the team control system at TKUT. Those opportunities could be found in two main directions: increasing the teams' evaluations by input variables and improving the planning system of teams' performance at TKUT.

The main conclusions from the research conducted at TKUT are the following:

- The application of the author's team control model at TKUT had a beneficial effect on the performance of the lecturing teams studied in 2015-2016 academic year. This effect consisted in the actual progress in 
the teams' performance realised in that period.

- Generally, it could be concluded that the team control committee at TKUT formed and implemented an appropriate set of managerial decisions by which the lecturing teams' performance for 2015-2016 academic year were improved.

- The author's team control model was successfully implemented at TKUT for 2015-2016 academic year. This conclusion is based on the fact that lecturing teams achieved their objectives for that period.

\section{CONCLUSIONS}

The author has come to three key conclusions regarding the achieved research results:

Firstly, the results prove research evidence in support of the thesis formulated in this paper. They show that it is possible to develop a model for the team control process combining achievements of management and fuzzy theories, and increasing effectiveness of that process. In evidence to this thesis, the author suggests an original team control model and a toolkit for measurement and evaluation of team performance. The model and the toolkit are developed at a contemporary scientific level and are considered to be elements of the theoretical and methodical fundamentals of team control. The operation of the team control model was tested empirically for a Bulgarian University. The practical applicability of the toolkit could be achieved by developing a relevant computer program.

Secondly, the suggested team control model measures and evaluates qualitatively/ quantitatively, unlike most existing models, the results from managerial decisions applied to improve team performance.

Thirdly, the suggested team control model sets better prerequisites for performing the team approach role as a key strategy for organizational success.

\section{КОНТРОЛА ТИМОВА: МОДЕЛ И ЕМПИРИЈСКИ ДОКАЗИ ИЗ БУГАРСКЕ}

\section{Maya Lambovska}

\section{Извод}

Овај рад сугерише један оригиналан модел за контролу тимова. Оригналност модела је повезана са комбинацијом менаџмент концепта и математичких теорија фази логике и фази скупова. Поред модела контроле тима, аутор предлаже алат за мерење и процену успешности тима. У примењеној методологији су укључене фази технике и алати за квантификацију евалуације, доношење одлука, проучавање заједничких утицаја и скривених ефеката. У овом раду су представљени и разматрани резултати испитивања модела контроле тима на једном бугарском универзитету.

Кључне речи: тим, контрола, процена учинка, фази логика 


\section{References}

Aubert, N. etc. (1991). Management. Paris: PUF.

Božanić, D., Pamučar, D., \& Bojanić, D. (2015). Modification of the analytic hierarchy process (AHP) method using fuzzy logic: Fuzzy AHP approach as a support to the decision making process concerning engagement of the group for additional hindering. Serbian Journal of Management, 10(2), 151-171.

Bojadziev, G., \& Bojadziev, M. (1997). Fuzzy logic for business, finance, and management. Singapore: World Scientific publishing.

Burns, L., Bradley, E., \& Weiner, B. (2012). Shortell and Kaluzny's health care management: Organization design \& behaviour. Clifton Park, NY: Delmar Cengage learning.

Caldwell, Ch. (2000). Performance management. USA: American Management Association.

Guinn, K. (1987). Performance management: not just an annual appraisal. Personnel, August, 39-42.

INTOSAI. (2004). Guidelines for performance audit Sofia: Bulgarian Audit Office http://www.bulnao.government.bg/files/_bg/ Ukazania-INTOSAI_ALL.doc . (in Bulgarian).

Ilgen, D., \& Schneider, J. (1991). Performance measurement: a multidiscipline view. International Review of Industrial and Organizational Psychology, 6, 71-108.

Kaufmann, A., \& Gil-Aluja, J. (1990). Laz matematicas del azar y de la incertidumbre. Madrid: Ediciones Graficas Ortega.

Kolev, P., Todorova, D., \& Gergova, N. (2012). Electronic forms of training - opportunities and prospects for Todor Kableshkov University of Transport. Pp. 343-369 in Proceedings of ISC "Management 2012", Belgrade: University of Belgrade.

Kozlowski, S., \& Bell, B. (2013). Work groups and teams in organizations. Pp. 412469 in N. Schmitt \& S. Highhouse (Eds.), Handbook of Psychology: Industrial and Organizational Psychology, Vol. 12, New Jersey: John Wiley \& Sons.

Margerison, Ch., \& McCann, D. (1990). Team Management: Practical New Approaches. London: Mercury Books.

McIntyre, R., \& Tedrow, L. (2004). A theory-based approach to team performance assessment. Pp. 443-451 in J. Thomas (Ed.), Comprehensive handbook of psychological assessment: Industrial and organizational assessment, Vol. 4, New Jersey: John Wiley \& Sons.

Mintzberg, H. (2013). Organizational configurations

http://www.12manage.com/methods_mintzb erg_configurations.html/.

Parker, G. (2011). Teams players and teamwork: New strategies for developing successful collaboration. San Francisco, CA, USA: Jossey-Bass.

Salas, E., Stagl, K., \& Burke, C. (2004). 25 years of team effectiveness in organization: Research themes and emerging needs. International Review of Industrial and Organizational Psychology, 19, 47-92.

Slavić, A., Berber, N., \& Leković, B. (2014). Performance management in international human resource management: Evidence from the CEE region. Serbian Journal of Management, 9(1), 45-58.

Simeonov, O. (2010). Conceptual aspects of the contemporary development of management control, Sofia: VUZF. (in Bulgarian). 
Živković, Ž., Nikolić, D., Mihajlović, I., \& Djordjević P. (2016). Dependability assessment of supplier performance based on fuzzy sets theory. Pp. 43-56 in Pál Michelberger (Ed.), Management, Enterprise and Benchmarking in the 21 st century, Budapest: Óbuda University, Keleti Faculty of Business and Management. 